\title{
Origin and source characterization of methane in the shallow-water environment of Southern Lake Tanganyika Rift Basin, Tanzania
}

\author{
Januarius Matata Bishanga and Jin Qiang* \\ School of Geoscience, China University of Petroleum, Qingdao 266000, China
}

Lake Tanganyika, located in the western part of Tanzania between $3^{\circ} \mathrm{S}$ and $9^{\circ} \mathrm{S}$ lat, harbours hydrocarbon and non-hydrocarbon gases in its northern and southern shallow-water environment. In this study, a geochemical analysis of stable carbon and hydrogen isotopes and an interpretation of individual gas molecular composition were done in order to determine the origin and composition of the naturally occurring hydrocarbon gases in Tanganyika Basin. Nitrogen, a non-hydrocarbon gas is a major component $(76.69 \%-78.31 \%)$ by volume percentage followed by methane (11.68\%-12.94\%) and other higher hydrocarbons $(0.16 \%-1.63 \%)$. The isotopic composition of carbon $\delta^{13} \mathrm{C}_{1}$ and hydrogen $\delta \mathrm{DC}_{1}$ ranges from $-65.32 \%$ to $-65.81 \%$ and $-272.5 \%$ to $-275.9 \%$ respectively. The isotopic compositions of ethane $\left(\delta \mathrm{DC}_{2}=\right.$ $-36.7 \%$ to $-35.2 \%$ ) and propane $\left(\delta \mathrm{DC}_{3}=-31.3 \%\right.$ to $-27.5 \%$ ) reflect the thermogenic origin of these higher hydrocarbons. According to molecular characterization of carbon and hydrogen isotope ratios and $\delta \mathrm{D}$-values, methane gas falls in the biogenic origin category and is formed by carbon dioxide reduction. The isotopic composition of $\mathrm{CO}_{2}$ varies between $-8.6 \%$ and $-3.4 \%$. $\mathrm{CO}_{2}$ reduction is also regarded as a mechanism of biogenic methane formation based on carbon isotope fractionation factors (greater than 0.16 ).

Keywords: Biogenic origin, isotopic composition, methane, molecular characterization, shallow-water environment.

Methane $\left(\mathrm{CH}_{4}\right)$ gas venting in Lake Tanganyika, Tanzania has drawn the attention of several researchers, debating on its origin and mechanism of occurrence. The origin, molecular characterization and maturity evaluation of hydrocarbon gases in lacustrine settings have long been propounded using hydrocarbon molecular content (methane/(ethane + propane); $\mathrm{C}_{1} / \mathrm{C}_{2+}$ or $\mathrm{C}_{1} /\left(\mathrm{C}_{2}+\mathrm{C}_{3}\right)$; commonly termed the Bernard parameter) and isotope carbon composition $\left(\delta^{13} \mathrm{C}_{1}\right)^{1-5}$. These gases are composed mainly of methane $\left(\mathrm{C}_{1}\right)$ with minor amounts of ethane $\left(\mathrm{C}_{2}\right)$, higher hydrocarbons $\left(\mathrm{C}_{3+}\right)$, nitrogen $\left(\mathrm{N}_{2}\right)$ and carbon

\footnotetext{
*For correspondence. (e-mail: jinqiang@upc.edu.cn)
}

dioxide $\left(\mathrm{CO}_{2}\right)$. The gases can be produced through biogenic (microbially-derived) or thermogenic (petroleumderived) processes ${ }^{6}$. The significant range in carbon and hydrogen molecular composition and stable isotope composition ratios of hydrocarbon gases render interpretative details regarding the gases and their concentration in lacustrine basins depending on environmental settings.

Globally, hydrothermally active regions are characterized by traces of gas anomalies in the freshwater/ seawater (plumes) or in the sediments ${ }^{7-10}$. Tropical lakes accumulate approximately one-quarter of the Earth's freshwater $^{11}$ and bear a substantial amount of hydrocarbons like methane and non-hydrocarbons like $\mathrm{CO}_{2}$ (greenhouse gases). Most East African rift lakes are hydrothermally active and contribute an enormous amount of carbon in the lakes' water column. Till date, the contribution of these rift lakes of $\mathrm{CH}_{4}$ gas to the atmosphere is unknown ${ }^{12}$. The Ocean Drilling Programme in Middle Valley, Juan De Fuca Ridge, Leg 1391, East African rift lakes showed the presence of thermogenic gases in the area. The evidence for thermogenic hydrocarbons included elevated contents of higher hydrocarbons $\left(\delta^{13} \mathrm{C}_{1}=\right.$ $-30.0 \%$ o to $-45.0 \%$ ) and based on the geologic setting, it is highly probable that the thermogenic gases were formed by hydrothermal processes. However, there is possible evidence of a bacterial gas component admixed with the thermogenic gases. The biogenic hydrocarbons in the free gas are concentrated below the thermocline where bacterial sulphate reduction has removed most or all of the dissolved sulphate ${ }^{3}$.

Schoell et al. ${ }^{13}$ discussed the origin of significantlyhigh methane gas concentration in Lake Kivu, north of Lake Tanganyika along the rift system, stating that methane gas $\left(\mathrm{C}_{1}\right)$ was formed by bacterial activity through acetate fermentation and $\mathrm{CO}_{2}$ reduction. Further they mentioned that along Lake Kivu and the northern trough of Lake Tanganyika, thermal springs exist and gases vent through the water column, which is associated with both biogenic and hydrothermal origin ${ }^{13-18}$. Climate variability, dry and hot conditions lead to decreased lake level by evaporation and changes in aqueous $\mathrm{CO}_{2}$ concentration. This phenomenon coupled with increased $\mathrm{pH}$ and salinity led to reduced dissolved $\mathrm{CO}_{2}$ concentration ${ }^{19}$. 
Botz and Stoffers ${ }^{7}$ suggested that active hydrothermalism occurs in the shallow-water environment of northern Lake Tanganyika. The major gaseous component of magmatic origin is carbon dioxide $\left(\delta^{13} \mathrm{C}=-9.1 \%\right.$ to $-3.8 \%$ ). Other variable light hydrocarbons were also detected. The isotopic composition of methane $\left(\delta^{13} \mathrm{C}_{1}=\right.$ $-58.0 \%$ o to $-50.4 \%$; $\delta \mathrm{DC}_{1}=-199 \%$ to $-149 \%$ ) indicated both a bacterial and thermogenic source for the hydrothermal gas. The $\delta \mathrm{DC}_{1}$ values, however, indicated that most of the bacterial methane is likely formed by $\mathrm{CO}_{2}$ reduction. Rudd $^{20}$ also carried out significant work on methane oxidation in Lake Tanganyika.

Various researchers have developed different hypotheses to explain the origin of these gases. According to Deines $^{21}$, Rohrback et al. ${ }^{22}$ and Chung et al. ${ }^{23}$, the carbon isotope $\left(\delta^{13} \mathrm{C}\right)$ composition of sedimentary organic matter in geologic age ranges between $-35 \%$ and $-20 \%$. The carbon isotope composition of methane derived from the thermogenic decomposition of organic matter ranges between $-50 \%$ and $-20 \%$, whereas abiogenic methane has $\delta^{13} \mathrm{C}$ values between $-110 \%$ to $-50 \%$ o (refs 3 and 5 ). The carbon isotopic compositions of methane and ethane, are used to determine the kerogen type of gas source rocks ${ }^{24-29}$.

Microbial hydrocarbons are usually generated from complex hydrocarbons, shallow-depth environments and reasonably low temperatures $\left(<80^{\circ}-100^{\circ} \mathrm{C}\right)$. Also, their stable carbon isotope composition ratios increase with increasing carbon number $\left(\mathrm{C}_{1} \delta^{13} \mathrm{C}<\mathrm{C}_{2} \delta^{13} \mathrm{C}<\mathrm{C}_{3} \delta^{13} \mathrm{C}\right)^{30,31}$. Further distinct characteristics of biogenic gases include low concentrations of higher $\mathrm{C}_{2+}$ hydrocarbons (low $\mathrm{C}_{2+} / \mathrm{C}_{1}$ ) and isotopically $\delta^{13} \mathrm{C}$ light methane $\left(\mathrm{C}_{1}<-60 \%\right)^{32,33}$.

In deep lakes like Tanganyika with anoxic bottom waters, methane oxidizes through a narrow zone in the upper boundary during water stratification. The methane oxidizers consume all the methane as it diffuses through the upper boundary. This phenomenon leads to low concentration in the oxic water layer and increase in the anoxic zone ${ }^{17,20}$. Tanganyika rift basin also receives a large amount of terrestrial organic matter; therefore, the generation of abundant nitrogen gas from the decomposition of organic matter in the Lake Tanganyika is inevitable.

Comprehensive geochemical works have been carried out to determine the origin of methane in northern Tanganyika Basin ${ }^{7,13,34,35}$. This study, therefore, focuses on gas samples collected in two different seasons in the southern Tanganyika Basin. An extensive and concise geochemical interpretation of individual gas molecular composition and isotopes will offer empirical evidence on the origin and composition of the naturally occurring hydrocarbon gases in the southern Tanganyika Basin.

\section{Lake Tanganyika hydrology and geology}

Lake Tanganyika, situated in the western region of Tanzania between $3^{\circ} \mathrm{S}$ and $9^{\circ} \mathrm{S}$ latitude at an altitude of about $773 \mathrm{~m}$ amsl, is a young (9-12 Ma), half-graben rift lake within the western branch of the Eastern Africa Rift System. Among the rift system lakes, it is the deepest $(\sim 1.47 \mathrm{~km})$ and the largest $(34,000$ sq. $\mathrm{km})$ in terms of contained volume of freshwater in the world, after Lake Baikal in the south of Russia ${ }^{20}$. The lake extends NW-SE and runs from north near Lake Kivu to the south near Lake Nyasa. The Lake borders with the Democratic Republic of Congo (DRC) on the west and Zambia on its southern shore.

The Lake is meromictic and below the depth of $150 \mathrm{~m}$, the waters and sediments are permanently stratified, anoxic, containing hydrogen sulphide, ammonia and phosphates $^{14,16,36}$. The Lake water is chemically mildly alkaline with a pH of 9 (refs 35,36$)$. Below the thermocline, sulphate concentration is significant and favours the formation of a chemically appropriate environment for anaerobic oxidation of methane.

The Lake and the region around it experience a tropical climate (semi-humid). The late Pleistocene-Holocene sediment accumulation rates are estimated to be 0.4 $0.5 \mathrm{~mm} /$ year for the deep waters $(>600 \mathrm{~m})$ basinal settings and could be less on structural highs ${ }^{16}$. This makes Lake Tanganyika a potential site for hydrocarbon explorations ${ }^{37}$. Large amounts of organic-rich sediments have been deposited in this Lake for sufficient organic matter supply, deep water and anoxic condition. The biological precursors for organic matter are mainly diatoms ${ }^{38}$. Stratified waters and organic-rich sediments in the Lake control the formation of high-potential source rocks ${ }^{15,36,39,40}$.

Lake Tanganyika consists of several sub-basins with three main depositional basins, namely the northern basin also called the Rusizi sub-basin, the Kigoma sub-basin and the southern sub-basin, separated by the Ubwari and Kalemie horst blocks respectively. The basins consist of half-grabens, with border faults and an accommodation zone separating the north and south basins ${ }^{37,41}$. The depositional basins are normally faulted with more than $4 \mathrm{~km}$ of sediments deposited in the deepest parts of the fault boundaries ${ }^{37}$. The resultant tectonic setting defines discrete structural forms within the lake, such as border fault margins, littoral platforms, midlake structural highs and axial-deep basins ${ }^{42,43}$.

Studies show that Lake Tanganyika continuously experiences an increase in gross and organic carbon (OC) sedimentation due to: (i) enhanced internal upwelling as a result of hydrological changes; (ii) increased terrestrial nutrient inputs caused by increased anthropogenic activities and/or (iii) modified internal food $\mathrm{web}^{36,44}$.

\section{Materials and method}

The method employed in this study was developed after McAuliffe $^{45}$. The headspace equilibration method was modified to increase sensitivity and storage of samples prior to analysis. The method is designed for open-ocean surface water, freshwater lakes, rivers and groundwater samples collection. 


\section{Materials}

Major reagents used were potassium hydroxide $(\mathrm{KOH})$ and sodium hydroxide $(\mathrm{NaOH})$ pellets. The $125 \mathrm{ml}$ glass serum bottles used for the headspace equilibration were from the organic geochemistry laboratory of the China University of Petroleum. Black and blue thick butyl rubber stoppers $(1 \mathrm{~cm})$ that sealed the glass serum bottles were also from the University laboratory. The plastic syringes used were $3 \mathrm{ml}$, luer lock syringes. Stopcocks were all three-way, polycarbonate, Luer-fitted. Needles were $21 \mathrm{G}$ or $22 \mathrm{G}$ Precision Glide-type needles. The ultrahigh purity grade helium gas, $\mathrm{KOH}$ and $\mathrm{NaOH}$ pellets were all of the analytical grade and purchased from Beijing Chemical Company in China.

\section{Experimental procedure}

Eleven gas samples were collected from shallow water (2-33 $\mathrm{m}$ water depth) in the southern Tanganyika Basin (Figure 1) and sampled using a rosette equipped with Niskin bottles. After retrieval, the bottles were subsampled immediately to minimize any equilibration of water contained in the Niskin bottles with air. Upon filling, the serum bottles were flushed at least two volumes of water to withdraw air bubbles, prevent contamination, and ensure that the water in the bottle was not exposed to air. Next, $0.5 \mathrm{ml}$ of $8 \mathrm{~mol} \mathrm{l}^{-1} \mathrm{KOH}$ solution was immediately added to the bottles using a $1 \mathrm{ml}$ syringe inserted as far as possible in the bottle to avoid air bubbles and contamination and which contained no traces of methane. The $\mathrm{KOH}$ solution was prepared at least a day prior to insertion into the bottle to let it equilibrate with air. However,

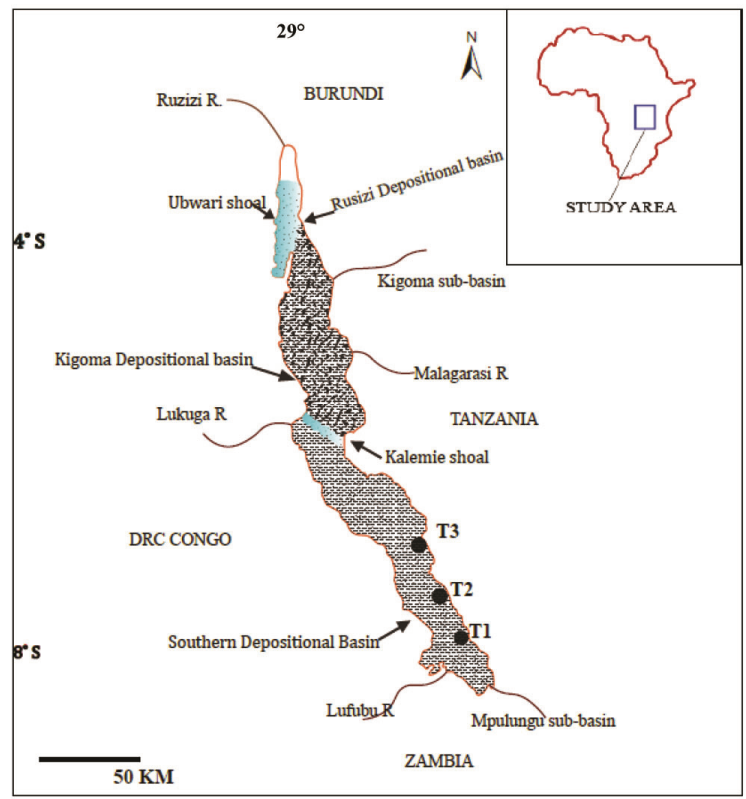

Figure 1. Schematic map of Lake Tanganyika showing the sampling sites T1, T2 and T3 in the southern depositional basin. Kigoma and Rusizi (Ruzizi) are the other depositional basins. it is advised to use $\mathrm{KOH}$ solution as opposed to adding $\mathrm{KOH}$ pellets directly to the sample to avoid contamination with methane. The bottles were then capped without headspace using butyl rubber stoppers probed with a needle connected to a $3 \mathrm{ml}$ syringe to allow air and water to leave the bottle when the stopper was inserted. The residual water in the syringe blocked back-injection of air when the needle was withdrawn. This also allowed water to expand or contract as the temperature of the sample equilibrates to laboratory temperature.

Once all Niskin bottles were subsampled and the samples had attained room temperature, the needles and syringes were withdrawn and the stoppers secured with aluminium crimps. To prevent bottle cracking due to temperature variations, a $10 \mathrm{ml}$ headspace of methanefree helium was added to the bottles using a $10 \mathrm{ml}$ syringe, a $21 \mathrm{G}$ or $22 \mathrm{G}$ needle and a three-way stopcock. At the same time, $10 \mathrm{ml}$ water was removed with a second syringe, needle and stopcock assembly. Once the headspace was added, the bottles were stored upside down to isolate gas from the stopper until analysis of the headspace methane. All the geochemical and stable carbon isotope composition analyses were performed using standard techniques as described by Schoell ${ }^{46,47}$. The methane carbon isotopes were determined using the method of Malanotte-Rizzoli et $a l .^{48}$, and results denoted in the common $\delta$-notation relative to Vienna Pee Dee Belemnite (VPDB). The methane concentrations were determined on a gas chromatograph (Agilent, 6890). Standard deviation (SD) and standard error (SE) were calculated to determine the consistency of the results. The SD of sample measurements taken in December 2013 and March 2014 was 0.49 and 0.45 , while SE was 0.22 and 0.19 respectively. When all datasets were combined, the SD and SE values were 0.47 and 0.14 respectively.

\section{Results}

Table 1 provides the location and approximate sampling depth for gas samples in the southern Tanganyika basin. Table 2 shows the results of the gas chromatographic analysis, which is the percentage of the various extracted gases (hydrocarbons and non-hydrocarbons) by volume assuming that the total is $100 \%$. The stable isotope data indicate methane as the predominant hydrocarbon gas present. The percentage by volume of $\mathrm{C}_{1}$ varies between 11.68 and 12.94, while the minimum amount of

Table 1. Locations (coordinates) and approximate water depths of gas samples in southern Tanganyika Basin

\begin{tabular}{lccc}
\hline Station & $\begin{array}{c}\text { Approximate } \\
\text { depth (m) }\end{array}$ & Easting (UTM) & Northing (UTM) \\
\hline T1 & 8 & 193,296 & $9,231,144$ \\
T2 & 15 & 238,020 & $9,147,091$ \\
T3 & 33 & 270,333 & $9,074,754$ \\
\hline
\end{tabular}


Table 2. Extracted gases percentage by volume in southern Lake Tanganyika

\begin{tabular}{|c|c|c|c|c|c|c|c|c|}
\hline \multirow[b]{2}{*}{ Sample ID } & \multicolumn{7}{|c|}{ Percentage } & \multirow[b]{2}{*}{$\mathrm{C}_{1} /\left(\mathrm{C}_{2}+\mathrm{C}_{3}\right)$} \\
\hline & $\mathrm{Ar}$ & $\mathrm{O}_{2}$ & $\mathrm{CO}_{2}$ & $\mathrm{~N}_{2}$ & $\mathrm{C}_{1}$ & $\mathrm{C}_{2}$ & $\mathrm{C}_{3}$ & \\
\hline T1-D-500-1 & 1.5 & 6.3 & 0.52 & 78.31 & 12.12 & 0.94 & 0.31 & 9.70 \\
\hline T1-D-500-2 & 1.6 & 6.4 & 0.54 & 77.53 & 12.64 & 1.05 & 0.24 & 9.80 \\
\hline T2-D-500-3 & 1.5 & 7.3 & 0.43 & 77.82 & 11.71 & 0.73 & 0.51 & 9.44 \\
\hline T3-D-500-2 & 1.6 & 7.1 & 0.52 & 77.85 & 11.68 & 0.84 & 0.41 & 9.34 \\
\hline T1-D-400-1 & 1.6 & 5.3 & 0.53 & 78.2 & 12.71 & 1.21 & 0.45 & 7.66 \\
\hline T1-D-400-1 & 1.52 & 6.55 & 0.55 & 77.12 & 12.94 & 0.98 & 0.34 & 9.80 \\
\hline T1-D-400-3 & 1.58 & 7.21 & 0.51 & 77.26 & 12.29 & 0.86 & 0.29 & 10.69 \\
\hline T2-C-200-1 & 1.53 & 6.95 & 0.49 & 76.69 & 12.9 & 0.79 & 0.65 & 8.96 \\
\hline T2-D-400-2 & 1.6 & 6.42 & 0.5 & 78.22 & 11.92 & 0.72 & 0.62 & 8.90 \\
\hline T3-D-500-1 & 1.48 & 7.1 & 0.55 & 77.84 & 11.95 & 0.92 & 0.16 & 11.06 \\
\hline T3-D-500-3 & 1.51 & 6.57 & 0.58 & 76.96 & 12.64 & 1.63 & 0.11 & 7.26 \\
\hline
\end{tabular}

Ar, Argon; $\mathrm{O}_{2}$, Oxygen; $\mathrm{CO}_{2}$, Carbon dioxide; $\mathrm{N}_{2}$, Nitrogen; $\mathrm{C}_{1}$, Methane; $\mathrm{C}_{2}$, Ethane: $\mathrm{C}_{3}$, Propane.

Table 3. Isotopic composition of methane $\left(\delta^{13} \mathrm{C}_{1}, \delta \mathrm{DC}_{1}\right)$, ethane $\left(\delta^{13} \mathrm{C}-\mathrm{C}_{2}\right)$, propane $\left(\delta^{13} \mathrm{C}-\mathrm{C}_{3}\right)$ and carbon dioxide $\left(\delta^{13} \mathrm{C}-\mathrm{CO}_{2}\right)$ from southern Lake Tanganyika

\begin{tabular}{|c|c|c|c|c|c|}
\hline Sample ID & $\begin{array}{c}\delta^{13} \mathrm{C}_{1} \\
(\% \text { versus } \mathrm{PDB})\end{array}$ & $\begin{array}{c}\delta \mathrm{DC}_{1} \\
(\% \text { versus VSMOW) }\end{array}$ & $\begin{array}{c}\delta^{13} \mathrm{C}-\mathrm{C}_{2} \\
(\% \text { versus } \mathrm{PDB})\end{array}$ & $\begin{array}{c}\delta^{13} \mathrm{C}-\mathrm{C}_{3} \\
(\% \text { versus } \mathrm{PDB})\end{array}$ & $\begin{array}{c}\delta^{13} \mathrm{C}-\mathrm{CO}_{2} \\
(\% \text { versus } \mathrm{PDB})\end{array}$ \\
\hline T1-D-500-1 & -65.40 & -274.4 & -35.4 & -30.1 & -8.3 \\
\hline T1-D-500-2 & -65.46 & -272.5 & -36.6 & -30.3 & -6.8 \\
\hline T2-D-500-3 & -65.75 & -274.7 & -35.2 & -29.8 & -5.7 \\
\hline T3-D-500-2 & -65.73 & -275.7 & -35.7 & -29.3 & -3.4 \\
\hline T1-D-400-1 & -65.77 & -274.8 & -35.3 & -29.3 & -4.7 \\
\hline T1-D-400-1 & -65.32 & -274.5 & -35.2 & -30.6 & -8.6 \\
\hline T1-D-400-3 & -65.57 & -272.7 & -36.1 & -31.3 & -6.1 \\
\hline T2-C-200-1 & -65.45 & -274.6 & -35.8 & -29.4 & -4.7 \\
\hline T2-D-400-2 & -65.48 & -275.9 & -36.7 & -28.3 & -3.8 \\
\hline T3-D-500-1 & -65.60 & -274.9 & -35.9 & -29.8 & -4.1 \\
\hline T3-D-500-3 & -65.81 & -274.6 & -36.6 & -27.5 & -3.7 \\
\hline
\end{tabular}

VSMOW, Vienna Standard Mean Ocean Water - an isotopic water benchmark used for both hydrogen and oxygen isotopes; PDB, Pee Dee Belemnite - for carbon isotopes in organic matter.

higher hydrocarbons ethane to propane varies from 0.16 to 1.63 . The gas ratios $\mathrm{C}_{1} /\left(\mathrm{C}_{2}+\mathrm{C}_{3}\right)$, i.e. methane/ (ethane + propane) range from 7.26 to 11.06 (Table 2 ). The $C_{1} /\left(C_{2}+C_{3}\right)$ ratio is an indicator of the origin of the gases and decreases with depth towards the Basin depocentres. Most researchers relate these trends to the deeper generation of thermogenic wet gases while at shallower depths, late-stage microbial gas is subject to meteoric recharge ${ }^{1,49,50}$. The isotopic composition of carbon $\delta^{13} \mathrm{C}_{1}$ and hydrogen $\delta \mathrm{DC}_{1}$ ranges from $-65.32 \%$ to $-65.81 \%$ and $-272.5 \%$ to $-275.9 \%$ respectively (Table 3 ). The isotopic composition of carbon dioxide varies between $-8.6 \%$ and $-3.4 \%$ (Table 4 ), falling in the range of magmatic origin. However, thermogenic $\mathrm{CO}_{2}$ should be less in carbon isotope as it is derived from decarboxylation reactions of organic matter ${ }^{2,13}$.

\section{Discussion}

\section{Methane, carbon and hydrogen isotope ratios}

Natural gas, also called fossil gas, is found in a wide variety of environments. Methane is a major constituent of natural gas, but the latter also contains heavier hydrocarbons (ethane, propane, butane), small amounts of nitrogen, carbon dioxide, hydrogen sulphide, rare gases and trace amounts of water. Natural gas can be generated through two processes, viz. microbial and thermogenic. The carbon $\delta^{13} \mathrm{C}_{1}$ and hydrogen $\delta \mathrm{DC}_{1}$ isotopes and molecular compositions are used to determine the methane gas origin and generation pathways. The most important parameters used to distinguish the gas types are their isotopic composition of stable carbon $\delta^{13} \mathrm{C}_{1}$ and hydrogen $\delta \mathrm{DC}_{1}$ along with the relative abundance of methane to other hydrocarbon gases $2,3,5,33,47,51$. The different types of methane have characteristic carbon and hydrogen isotope compositions, which vary with source type and maturity in the case of thermogenic methane ${ }^{5}$. The carbon isotope compositions of methane derived from the primary thermogenic decomposition of organic matter ranges between $-50 \%$ and $-20 \%$, whereas biogenic methane has $\delta^{13} \mathrm{C}_{1}$ values between -110 and $-50 \%$ and less than $-60 \%$ for carbon dioxide reduction pathway ${ }^{3,5,49,52}$. An intermediate methane carbon isotope composition between $-50 \%$ and $-60 \%$ may be interpreted as mixing origins between microbial and thermogenic gases ${ }^{49,53}$. The combination of 


\section{RESEARCH ARTICLES}

carbon and hydrogen isotope analysis of natural gas is therefore an important approach to decipher the different origins of gases.

The hydrocarbon composition of methane can also be quantified in a number of ways, such that it is important to precisely distinguish between gas dryness and wetness. The ratio of methane to the sum of ethane and propane $\left(\mathrm{C}_{1} /\left(\mathrm{C}_{2}+\mathrm{C}_{3}\right)\right)$ is extensively used to distinguish between microbial and thermogenic gases. The ratio of methane to the sum of ethane and propane greater than 1000 and less than 100 (wet gases analogous with oil show $\left.\left(\mathrm{C}_{1} /\left(\mathrm{C}_{2}+\mathrm{C}_{3}\right)\right)<50\right)$ is an indicator of microbial and thermogenic gas respectively, when used in combination with methane carbon isotope composition ${ }^{3,49-51,54,55}$. Table 3 shows the isotopic composition of methane $\left(\delta^{13} \mathrm{C}_{1}, \delta \mathrm{DC}_{1}\right)$, ethane $\left(\delta^{13} \mathrm{C}-\mathrm{C}_{2}\right)$, propane $\left(\delta^{13} \mathrm{C}-\mathrm{C}_{3}\right)$, and carbon dioxide $\left(\delta^{13} \mathrm{C}-\mathrm{CO}_{2}\right)$ from the southern Tanganyika Basin. The isotopic composition of carbon $\delta^{13} \mathrm{C}_{1}$ and hydrogen $\delta \mathrm{DC}_{1}$ ranges from $-65.32 \%$ to $-65.81 \%$ and $-272.5 \%$ to $-275.9 \%$ respectively. Various diagrams previously developed for the classification of natural gases, including the Schoell ${ }^{5}$ and Whiticar ${ }^{51}$ diagrams, have been used to determine the origin of methane. The most widely used is the Bernard diagram (modified after Bernard et $\left.a l .{ }^{54}\right)$, which compares the molecular ratio of $\mathrm{C}_{1} /\left(\mathrm{C}_{2}+\mathrm{C}_{3}\right)$ with $\delta^{13} \mathrm{C}-\mathrm{CH}_{4}$ to distinguish between microbial (biogenic) and thermogenic gases.

Figure 2 displays the $\delta{ }^{13} \mathrm{C}_{1}$ against $\delta \mathrm{DC}_{1}$ plot comprising isotopic data for methane from southern Lake Tanganyika. According to the original diagram (refer to Whiticar ${ }^{56}$ ), methane gas from Tanganyika Basin falls in the category of bacterial/biogenic origin.

Figure 3 shows the isotopic composition of biogenic methane within the isotopic fields of $\mathrm{CO}_{2}$ reduction. Therefore, $\mathrm{CO}_{2}$ reduction is a controlling mechanism of biogenic methane formation in Lake Tanganyika. However, according to the Bernard diagram (Figure 4), methane in southern Lake Tanganyika falls in the region of mixed origin (biogenic and thermogenic) which agrees with the relative amounts of higher hydrocarbons $\left(\mathrm{C}_{2}\right.$ and $\left.\mathrm{C}_{3}\right)$ by comparing the molecular $\left(\mathrm{C}_{1} /\left(\mathrm{C}_{2}+\mathrm{C}_{3}\right)\right)$ ratio with

Table 4. Isotopic composition of carbon dioxide from shallow waters in southern Lake Tanganyika

\begin{tabular}{lcc}
\hline Sample ID & $\mathrm{CO}_{2}(\%)$ & $\delta^{13} \mathrm{C}-\mathrm{CO}_{2}(\%$ versus PDB $)$ \\
\hline T1-D-500-1 & 0.52 & -8.3 \\
T1-D-500-2 & 0.54 & -6.8 \\
T2-D-500-3 & 0.43 & -5.7 \\
T3-D-500-2 & 0.52 & -3.4 \\
T1-D-400-1 & 0.53 & -4.7 \\
T1-D-400-1 & 0.55 & -8.6 \\
T1-D-400-3 & 0.51 & -6.1 \\
T2-C-200-1 & 0.49 & -4.7 \\
T2-D-400-2 & 0.50 & -3.8 \\
T3-D-500-1 & 0.55 & -4.1 \\
T3-D-500-3 & 0.58 & -3.7 \\
\hline
\end{tabular}

the $\delta^{13} \mathrm{C}-\mathrm{CH}_{4}$ isotopic composition. Despite the presence of minimum amount of higher hydrocarbons, i.e. ethane, propane, etc. the source interpretation is confirmed by the Bernard diagram ${ }^{54}$. The isotopic composition of ethane $\left(\delta \mathrm{DC}_{2}=-36.7 \%\right.$ o to $\left.-35.2 \%\right)$ and propane $\left(\delta \mathrm{DC}_{3}=\right.$ $-31.3 \%$ to $-27.5 \%$ ) reflect the thermogenic origin of these higher hydrocarbons. This makes it hard to rule out methane origin from thermogenic processes as well. The generation of $\mathrm{N}_{2}$ and methane may have occurred by the process of thermal decomposition of humic organic matter, based on the quantity of $\mathrm{N}_{2}$ gas, while the most important methane-producing pathways in lacustrine sediments are biogenic (methanogenesis from acetate) and $\mathrm{CO}_{2}$ reduction ${ }^{57}$.

The fermentation process in shallow deposited sediments contributes to the formation of biogenic methane in Lake Tanganyika and both processes (fermentation and $\mathrm{CO}_{2}$ reduction) may be involved. Bacterial oxidation

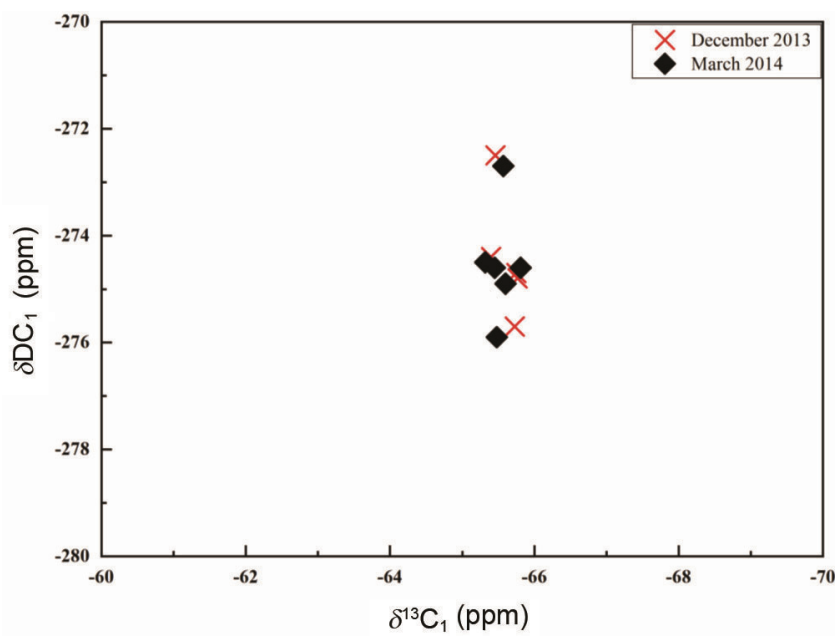

Figure 2. Plot of $\delta^{13} \mathrm{C}_{1}$ versus $\delta \mathrm{DC}_{1}$ showing the isotopic composition of methane in southern Lake Tanganyika.

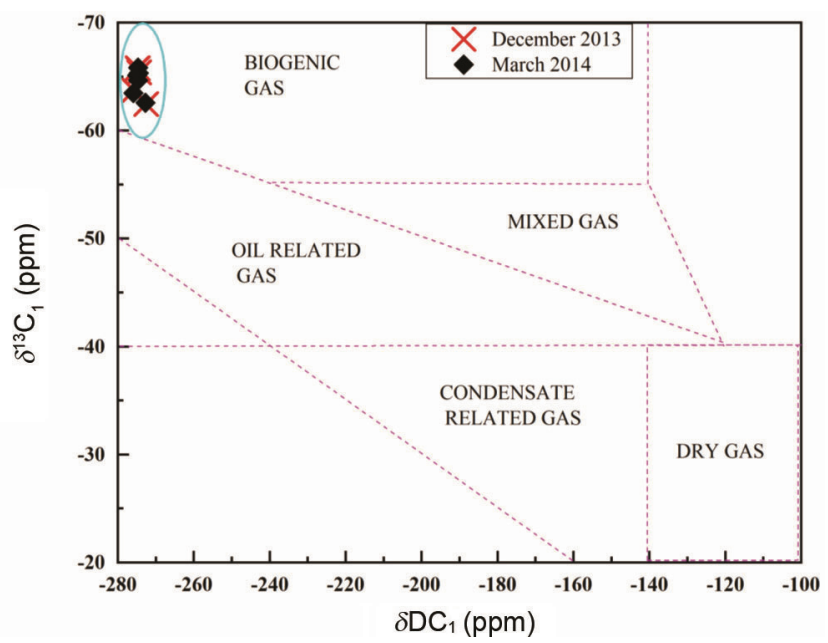

Figure 3. $\quad \delta^{13} \mathrm{C}_{1}$ against $\delta \mathrm{DC}_{1}$ plot showing the isotopic composition of methane from southern Lake Tanganyika (modified from Schoell ${ }^{47}$ and Whiticar ${ }^{56}$ ). 
significantly influences the production of methane rather than lighter hydrocarbons.

\section{Carbon $\delta^{13} C_{1}$ isotopic characterization}

Based on primary processes, the $\delta^{13} \mathrm{C}_{1}$ isotopic characterization of natural gases is related to the three main stages of thermal evolution of organic matter in sedimentary rocks, i.e. metagenetic $(-40 \%$ to $-25 \%)$, catagenetic $(-55 \%$ o to $-40 \%$ ) and diagenetic $(-90 \%$ o to $-55 \%$ ).

\section{Carbon dioxide carbon isotope composition}

The possible sources of $\mathrm{CO}_{2}$ in lake waters and sediments may include microbial degradation of organic substrates, dissolved $\mathrm{CO}_{2}$ from the atmosphere, magmatic/mantle origin, thermal decomposition of carbonates, and thermal maturation of kerogen ${ }^{49,58,59}$. The best way to evaluate the origin of $\mathrm{CO}_{2}$ is to assess the relationship between concentration and carbon isotopic composition. Gases with $\mathrm{CO}_{2}$ content greater than $10 \mathrm{vol} \%$, mostly have isotopic composition with $\delta^{13} \mathrm{C}_{1}$ values between $-3 \%$ and $-10 \%$, which fall in the range of $\mathrm{CO}_{2}$ from geothermal (magmatic) systems and are predominantly of magmatic/mantle origin. Gases with $\mathrm{CO}_{2}$ content less than $10 \mathrm{vol} \%$ display a wide range of $\delta^{13} \mathrm{C}$ values. Gases with $\mathrm{CO}_{2}$ content less than $10 \mathrm{vol} \%$ and isotopic composition in the inorganic range between $-3 \%$ and $-10 \%$ are probably thermogenic or mixtures and are affected by microbial degradation $^{49,53}$. In this study, the isotopic composition of carbon dioxide varies between $-8.6 \%$ and $-3.4 \%$ (Table 4 ), falling in the range of $\mathrm{CO}_{2}$ from geothermal (magmatic) systems (Figure 5).

During methanogenesis, the covariance of $\delta^{13} \mathrm{C}_{1}$ values of methane and carbon dioxide is presumed where

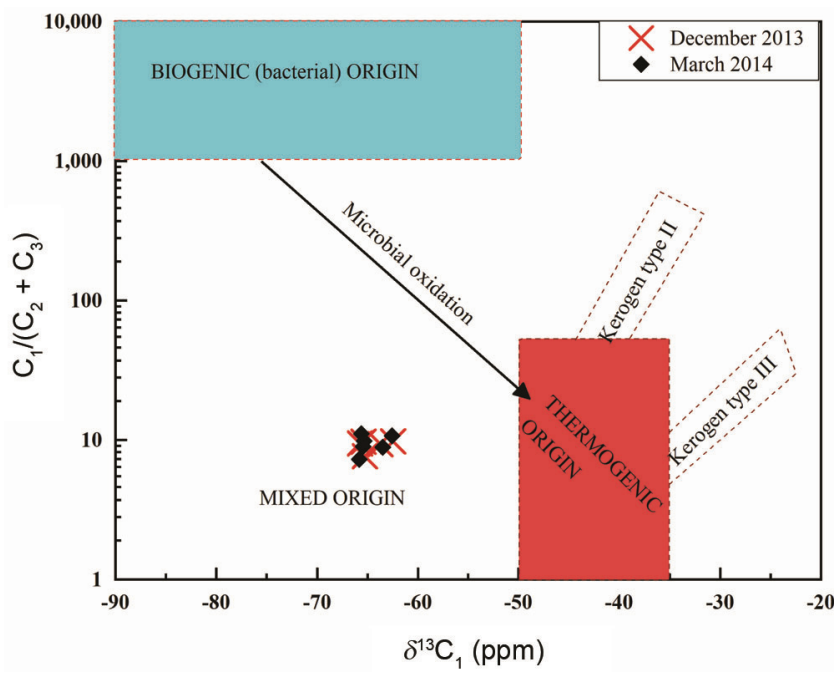

Figure 4. Schematic illustration of Bernard diagram for southern Lake Tanganyika gas samples modified from Schoell ${ }^{47}$ and Bernard et al. ${ }^{54}$. methanogens utilize the $\mathrm{CO}_{2}$ reduction pathway. The $\mathrm{CO}_{2}$ and $\mathrm{CH}_{4}$ isotopic composition values associated with carbonate reduction range from $-49 \%$ to over $-100 \%$. However, the most frequently observed values fall between $-60 \%$ and $-80 \%$. For acetate fermentation and methanogenesis utilizing methylated substrates, the $\mathrm{CO}_{2}$ and $\mathrm{CH}_{4}$ isotopic composition values are relatively low, with average values between $-40 \%$ and $-55 \%$ (refs $2,49,51$ and 60). A plot of $\delta^{13} \mathrm{C}-\mathrm{CO}_{2}$ against $\delta^{13} \mathrm{C}-\mathrm{CH}_{4}$ values shows the carbon isotope fractionation lines for various methanogenic pathways, where $\alpha \mathrm{CO}_{2}-\mathrm{CH}_{4}=\left(1000+\delta^{13} \mathrm{C}-\mathrm{CO}_{2}\right) /$ $\left(1000+\delta^{13} \mathrm{C}-\mathrm{CH}_{4}\right)^{49}$. The carbon isotope fractionation values between 1.03 and $1.06,1.06$ and 1.09 are characteristic of acetate and methyl-type fermentation

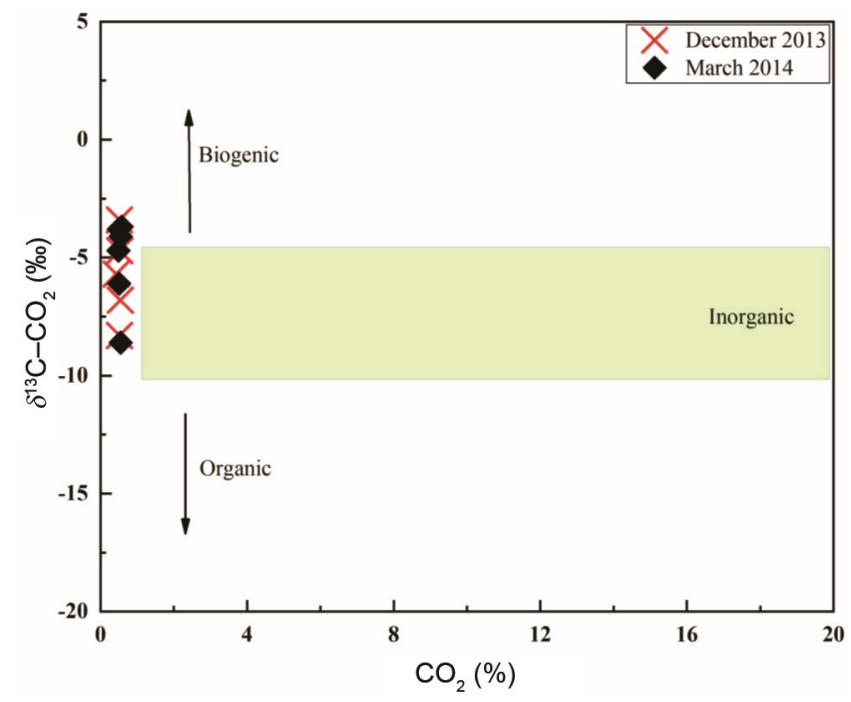

Figure 5. Carbon isotopic composition of $\mathrm{CO}_{2}$ versus molecular percentage of southern Lake Tanganyika methane. Organic - from thermal decomposition of organic matter; biogenic - influenced by microbial activity and inorganic - from igneous input (magmatic systems).

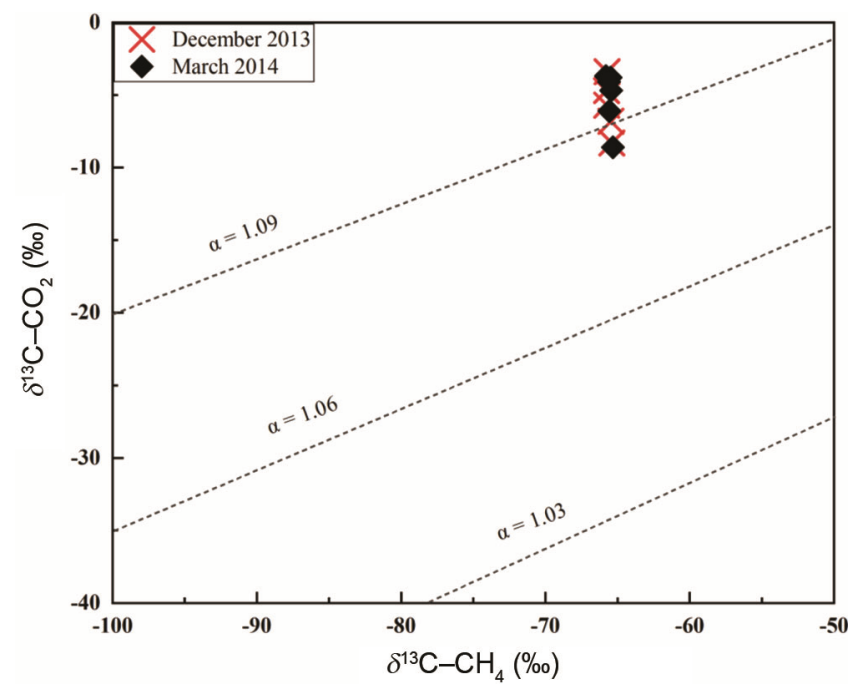

Figure 6. Plot of carbon dioxide $\delta^{13} \mathrm{C}$ versus methane $\delta^{13} \mathrm{C}$ values showing the carbon isotope fractionation lines for various methanogenic pathways in southern Lake Tanganyika. 
and $\mathrm{CO}_{2}$ reduction respectively ${ }^{49-51}$. This demonstrates that the carbon isotope fractionation between $\mathrm{CO}_{2}$ and $\mathrm{CH}_{4}$ (Figure 6) may as well be used to depict and distinguish between gases of microbial and thermogenic origin (Figure 6). The isotope fractionation factors reveal that $\mathrm{CO}_{2}$ reduction has been implicated in gas generation in Lake Tanganyika.

In this study, $\mathrm{N}_{2}$ percentage volume is higher in all samples (Table 2) and presumed to be the major gas component (76.69\%-78.31\%) in the Tanganyika Basin. This significant quantity suggests fermentation of autochthonous organic matter and deposition of clastic sediments in shallow depths. Water-column stratification and upwelling are important processes that introduce ammonia $\left(\mathrm{NH}_{3}\right)$ to the upper southern end water surfaces and assumed to be assimilated by planktons. A large proportion of $\mathrm{NH}_{3}$ introduced into the layer is lost either to the atmosphere or by oxidation to $\mathrm{N}_{2}$ in solution ${ }^{39}$. It can be concluded that thermocline and upwelling are significant processes for rapid oxidation to nitrogen in the southern Basin.

\section{Conclusion}

In addition to light hydrocarbon methane, southern Lake Tanganyika Basin contains sufficient quantities of other gases $\left(\mathrm{N}_{2}, \mathrm{O}_{2}\right.$ and $\left.\mathrm{Ar}\right)$. The isotopic composition of methane in Lake Tanganyika indicates biogenic origin with carbon $\delta^{13} \mathrm{C}_{1}$ and hydrogen $\delta \mathrm{DC}_{1}$ isotopic composition ranging from $-65.32 \%$ to $-65.81 \%$ and $-272.5 \%$ to $-275.9 \%$ respectively, while the gas ratios $C_{1} /\left(C_{2}+C_{3}\right)$ range from 7.26 to 11.06 of mixed origin. The isotopic compositions of ethane $\left(\delta \mathrm{DC}_{2}=-36.7 \%\right.$ o to $-35.2 \%$ ) and propane $\left(\delta \mathrm{DC}_{3}=-31.3 \%\right.$ to $-27.5 \%$ ) reflect the thermogenic origin of these higher hydrocarbons. $\mathrm{CO}_{2}$ reduction and fermentation are the processes for biogenic methane formation. The possible source of $\mathrm{CO}_{2}$ in lake waters is magmatic/mantle origin and its isotopic composition varies between $-8.6 \%$ and $-3.4 \%$. Moreover, the isotope fractionation factor values which fall above 1.06 show that $\mathrm{CO}_{2}$ reduction has been implicated in gas generation in the Tanganyika. There is evidence that more $\mathrm{CH}_{4}$ is produced from enormous autochthonous (derived from aquatic plants and phytoplankton) organic matter present in the deep southern Tanganyika Basin than from allochthonous (derived from land plants) organic matter. A high organic matter supply rate and accumulation can stimulate significant sediment $\mathrm{CH}_{4}$ formation and emission, especially for biologically reactive organic matter. Thermal decomposition of organic matter and oxidation of $\mathrm{NH}_{3}$ to $\mathrm{N}_{2}$ may have been the reason for $\mathrm{N}_{2}, \mathrm{CH}_{4}$ and $\mathrm{CO}_{2}$ gases in the southern Tanganyika Basin.

1. Rice, D. D. and Claypool, G. E., Generation, accumulation, and resource potential of biogenic gas. Am. Assoc. Pet. Geol. Bull., 1981, 65, 5-25.

2. Whiticar, M. J., Faber, E. and Schoell, M., Biogenic methane formation in marine and freshwater environments: $\mathrm{CO}_{2}$ reduction versus acetate fermentation - isotope evidence. Geochim. Cosmochim. Acta, 1986, 50, 693-709.

3. Whiticar, M. J., Faber, E., Whelan, J. K. and Simoneit, B. R., Thermogenic and bacterial hydrocarbon gases (free and sorbed) in Middle Valley, Juan de Fuca Ridge, Leg 139. In Proceedings of the Ocean Drilling Program, Scientific Results, Texas A and M University, TX, United States, 1994, pp. 467-477.

4. Yen, T. F. and Chilingar, G. V., A Review of: B. P. Tissot and D. H. Welte, Petroleum Formation and Occurrence. A New Approach to Oil and Gas Exploration, Springer-Verlag, Berlin, 1978, 538 pp. 243 Figures. Energy Sources, 1979, 4, 367-382.

5. Schoell, M., The hydrogen and carbon isotopic composition of methane from natural gases of various origins. Geochim. Cosmochim. Acta, 1980, 44, 649-661.

6. Tissot, B. and Welte, D., Petroleum Formation and Occurrence, Springer-Verlag, Berlin, Germany, 1984.

7. Botz, R. and Stoffers, P., Light hydrocarbon gases in Lake Tanganyika hydrothermal fluids (East-Central Africa). Chem. Geol., 1993, 104, 217-224.

8. Welhan, J. T. and Craig, H. J., Methane and hydrogen in East Pacific Rise hydrothermal fluids. Geophys. Res. Lett., 1979, 6, 829-831.

9. Whiticar, M. J. and Suess, E. J., Hydrothermal hydrocarbon gases in the sediments of the King George Basin, Bransfield Strait, Antarctica. Appl. Geochem., 1990, 5, 135-147.

10. Welhan, J. and Lupton, J., Light hydrocarbon gases in Guaymas Basin hydrothermal fluids: thermogenic versus abiogenic origin. Am. Assoc. Pet. Geol. Bull., 1987, 71, 215-223.

11. Bootsma, H. A. and Hecky, R. E. J., A comparative introduction to the biology and limnology of the African Great Lakes. J. Great Lakes Res., 2003, 29, 3-18.

12. Durisch-Kaiser, E. et al., What prevents outgassing of methane to the atmosphere in Lake Tanganyika? J. Geophys. Res., 2011, 116.

13. Schoell, M., Tietze, K. and Schoberth, S., Origin of methane in Lake Kivu (east-central Africa). Chem. Geol., 1988, 71, 257-265.

14. Coulter, G. W., Hydrological changes in relation to biological production in Southern Lake Tanganyika. Limnol. Oceanogr., 1963, 8, 463-477.

15. Craig, H. (ed.), Lake Tanganyika geochemical and hydrographic study: 1973 expedition. In Scripps Institution of Oceanography, University of California, San Diego, California, USA, p. 83.

16. Degens, E. T., Von Herzen, R. P. and Wong, H.-K., Lake Tanganyika: water chemistry, sediments, geological structure. Naturwissenschaften, 1971, 58, 229-241.

17. Degens, E. T., von Herzen, R. P., Wong, H.-K., Deuser, W. G. and Jannasch, H. W., Lake Kivu: structure, chemistry and biology of an East African rift lake. Geol. Rund., 1973, 62, 245-277.

18. Tiercelin, J.-J. et al., Hydrothermal vents in Lake Tanganyika, East African, Rift system. Geology, 1993, 21, 499-502.

19. Leng, M. J. et al. (eds), Isotopes in lake sediments. In Isotopes in Palaeoenvironmental Research, Springer, 2006, pp. 147-184.

20. Rudd, J. W., Methane oxidation in Lake Tanganyika (East Africa). Limnol. Oceanogr., 1980, 25, 958-963.

21. Deines, P., The isotopic composition of reduced organic carbon. In The Terrestrial Environment (eds Fritz, P. and Fontes, J. C.), Elsevier, Amsterdam, The Netherlands, pp. 329-406.

22. Peters, K., Rohrback, B. and Kaplan, I., Geochemistry of artificially heated humic and sapropelic sediments - I: Protokerogen. AAPG Bull., 1981, 65, 688-705.

23. Chung, H. M., Sackett, W. M. J. P. and Earth, C. O. T., Carbon isotope effects during the pyrolytic formation of early methane from carbonaceous materials. Phys. Chem. Earth, 1980, 12, 705-710.

24. Ni, Y. et al., Stable hydrogen and carbon isotopic ratios of coalderived and oil-derived gases: a case study in the Tarim basin, NW China. Int. J. Coal Geol., 2013, 116, 302-313.

25. Ping, H., Chen, H., Zhu, J., George, S. C., Mi, L., Pang, X. and Zhai, P., Origin, source, mixing, and thermal maturity of natural 
gases in the Panyu lower uplift and the Baiyun depression, Pearl River Mouth Basin, northern South China Sea. Am. Assoc. Pet. Geol. Bull., 2018, 102, 2171-2200.

26. Cramer, B., Faber, E., Gerling, P. and Krooss, B. M., Reaction kinetics of stable carbon isotopes in natural gas: insights from dry, open system pyrolysis experiments. J. Energy Fuels, 2001, 15, 517-532.

27. Hao, F., Guo, T., Zhu, Y., Cai, X., Zou, H. and Li, P., Evidence for multiple stages of oil cracking and thermochemical sulfate reduction in the Puguang gas field, Sichuan Basin, China. Am. Assoc. Pet. Geol. Bull., 2008, 92, 611-637.

28. Hoşgörmez, H., Yalçın, M. N., Cramer, B., Gerling, P. and Mann, U., Molecular and isotopic composition of gas occurrences in the Thrace basin (Turkey): origin of the gases and characteristics of possible source rocks. J. Chem. Geol., 2005, 214, 179-191.

29. Laughrey, C. D. and Baldassare, F. J., Geochemistry and origin of some natural gases in the Plateau Province, central Appalachian Basin, Pennsylvania and Ohio. Am. Assoc. Pet. Geol. Bull., 1998, 82, 317-335.

30. Chung, H., Gormly, J. and Squires, R. J., Origin of gaseous hydrocarbons in subsurface environments: theoretical considerations of carbon isotope distribution. J. Chem. Geol., 1988, 71, 97-104.

31. McCarty, H. B. and Felbeck Jr, G. T., High temperature simulation of petroleum formation - IV. Stable carbon isotope studies of gaseous hydrocarbons. J. Org. Geochem., 1986, 9, 183-192.

32. Machel, H., Bacterial and thermochemical sulfate reduction in diagenetic settings - old and new insights. J. Sediment. Geol., 2001, 140, 143-175.

33. Schoell, M., Genetic characterization of natural gases. Am. Assoc. Pet. Geol. Bull., 1983, 67, 2225-2238.

34. Deuser, W., Degens, E., Harvey, G. and Rubin, M., Methane in Lake Kivu: new data bearing on its origin. Science, 1973, 181, 51-54.

35. Gourgue, O., Deleersnijder, E., White, L., Toward a generic method for studying water renewal, with application to the epilimnion of Lake Tanganyika. J. Estuar. Coastal Shelf Sci., 2007, 74, 628-640.

36. Cohen, A. S. et al., Paleolimnological investigations of anthropogenic environmental change in Lake Tanganyika: IX. Summary of paleorecords of environmental change and catchment deforestation at Lake Tanganyika and impacts on the Lake Tanganyika ecosystem. J. Paleolimnol., 2005, 34, 125-145.

37. Rosendahl, B. et al., Structural expressions of rifting: lessons from Lake Tanganyika, Africa. Geol. Soc., London, Spec. Publ., 1986, 25, 29-43.

38. Huc, A. et al. (eds), Northern Lake Tanganyika: an example of organic sedimentation in an anoxic rift lake. In Laustrine Basin Exploration: Case Studies and Modern Analogs, AAPG Memoir, 1990, pp. 169-208.

39. Edmond, J., Stallard, R., Craig, H., Craig, V., Weiss, R. and Coulter, G., Nutrient chemistry of the water column of Lake Tanganyika. Limnol. Oceanogr., 1993, 38, 725-738.

40. Demaison, G. J. and Moore, G. T., Anoxic environments and oil source bed genesis. AAPG Bull., 1980, 64, 1179-1209.

41. Quennel, A., McKinley, A. and Aitken, W., Summary of the Geology of Tanganyika, Memoir I, Part II: Introduction and Stratigraphy, Government Printer, Dar es Salaam, Tanzamia, 1956, p. 264.

42. Tiercelin, J., Cohen, A., Soreghan, M. and Lezzar, K., Pleistocene-modern deposits of the Lake Tanganyika Rift Basin, East Africa: a modern analog for lacustrine source rocks and reservoirs. In SEPM Core Workshop, 1994, vol. 19, pp. 37-59.

43. Tiercelin, J.-J., Soreghan, M., Cohen, A. S., Lezzar, K.-E. and Bouroullec, J.-L., Sedimentation in large rift lakes: example from the Middle Pleistocene-modern deposits of the Tanganyika
Trough, East African Rift system. Bull. Centres Rech. Explor.Prod. Elf Aquitaine, 1992, 16, 83-111.

44. Pasche, N. et al., Abrupt onset of carbonate deposition in Lake Kivu during the 1960s: response to recent environmental changes. J. Paleolimnol., 2010, 44, 931-946.

45. McAuliffe, C., GC determination of solutes by multiple phase equilibration. A new general technique. Chem. Tech., 1971, 1, 46-51.

46. Schoell, M., Recent advances in petroleum isotope geochemistry. Org. Geochem., 1984, 6, 645-663.

47. Schoell, M., Multiple origins of methane in the Earth. Chem. Geol., 1988, 71, 1-10.

48. Malanotte-Rizzoli, P. et al., A synthesis of the Ionian Sea hydrography, circulation and water mass pathways during POEM-Phase I. Prog. Oceanogr., 1997, 39, 153-204.

49. Golding, S. D., Boreham, C. J. and Esterle, J. S., Stable isotope geochemistry of coal bed and shale gas and related production waters: a review. Int. J. Coal Geol., 2013, 120, 24-40.

50. Flores, R. M., Rice, C. A., Stricker, G. D., Warden, A. and Ellis, M. S., Methanogenic pathways of coal-bed gas in the Powder River Basin, United States: the geologic factor. Int. J. Coal Geol., 2008, 76, 52-75.

51. Whiticar, M. J., Carbon and hydrogen isotope systematics of bacterial formation and oxidation of methane. Chem. Geol., 1999, 161, 291-314.

52. Strąpoć, D. et al., Biogeochemistry of microbial coal-bed methane. Annu. Rev. Earth Planet. Sci., 2011, 39, 617-656.

53. Boreham, C. J., Edwards, D. S., Hope, J. M., Chen, J. and Hong, Z., Carbon and hydrogen isotopes of neo-pentane for biodegraded natural gas correlation. Org. Geochem., 2008, 39, 1483-1486.

54. Bernard, B. B., Brooks, J. M. and Sackett, W. M., Light hydrocarbons in recent Texas continental shelf and slope sediments. J. Geophys. Res.: Oceans, 1978, 83, 4053-4061.

55. Osborn, S. G. and McIntosh, J. C., Chemical and isotopic tracers of the contribution of microbial gas in Devonian organic-rich shales and reservoir sandstones, northern Appalachian Basin. Appl. Geochem., 2010, 25, 456-471.

56. Whiticar, M. J., A geochemial perspective of natural gas and atmospheric methane. Org. Geochem., 1990, 16, 531-547.

57. Conrad, R., Quantification of methanogenic pathways using stable carbon isotopic signatures: a review and a proposal. J. Organic Geochem., 2005, 36, 739-752.

58. Dai, J. et al., Geochemical characteristics of the abiogenic alkane gases in the Songliao Basin, China. In AAPG Hedberg Research Conference - Natural Gas Geochemistry: Recent Developments, Applications and Technologies, Beijing, China, 2011.

59. Pallasser, R., Recognising biodegradation in gas/oil accumulations through the $\delta^{13} \mathrm{C}$ compositions of gas components. Org. Geochem., 2000, 31, 1363-1373.

60. Jenden, P. and Kaplan, I., Comparison of microbial gases from the Middle America Trench and Scripps Submarine Canyon: implications for the origin of natural gas. Appl. Geochem., 1986, 1, 631646.

ACKNOWLEDGEMENTS. This work was supported by the Certificate of National Science and Technology Major Project of the Ministry of Science and Technology of China (2016ZX05006-007), National Natural Science Foundation of China (41702139), Natural Science Foundation of Shandong Province (ZR2017BD036) and the Fundamental Research Funds for the Central Universities (18CX02008A). We thank the Tanzania Petroleum Development Co-operation (TPDC) for providing geological datasets.

Received 24 June 2020; revised accepted 20 November 2020

doi: $10.18520 / \mathrm{cs} / \mathrm{v} 120 / \mathrm{i} 6 / 1066-1073$ 